\title{
Replacement Policy for Nuclear Energy for Peaceful Purposes: An Environmental Approach
}

\section{Shams Al Din Al Hajjaji}

To cite this article: Shams AI Din Al Hajjaji (2017) Replacement Policy for Nuclear Energy for Peaceful Purposes: An Environmental Approach, Environmental Claims Journal, 29:3, 235-241, DOI: $10.1080 / 10406026.2017 .1345527$

To link to this article: https://doi.org/10.1080/10406026.2017.1345527

曲 Published online: 25 Jul 2017.

Submit your article to this journal $\asymp$

山 Article views: 29

Q View related articles $\circlearrowright$ 


\title{
Replacement Policy for Nuclear Energy for Peaceful Purposes: An Environmental Approach
}

\author{
Shams AI Din AI Hajjaji \\ Judge, North Cairo Primary Court
}

\section{Introduction}

Nuclear energy is unequivocally important in global politics and technological advancement. The creation of weapons of mass destruction has inspired policies which chill our development of nuclear energy for mass consumption: the Treaty on the Non-Proliferation of Nuclear Weapons (NPT) stipulates a global ban on NENPP. ${ }^{1}$ This nuclear approach to nuclear energy is virtually unchallenged, even though some doubts have been raised as to the feasibility of nuclear energy as a weapon. Former U.S. Secretary of State General Colin Powell recently summarized his experience with nuclear weapons by describing them as "useless." In an interview, he stated: "After all these years of exposure to the use of nuclear weapons ... they are useless, and cannot be used." Although nuclear energy has lost appeal as a weapon, it persists as a major source of energy worldwide. ${ }^{4}$ It is used to generate 75 percent of France's electricity, ${ }^{5} 30$ percent to 40 percent of Japan's electricity, ${ }^{6}$ 20 percent of the United States' electricity, ${ }^{7}$ and 20 percent of Russia's electricity. ${ }^{8}$ Although there is pressure to continue this trend of positive applications of nuclear energy, nuclear power generation poses significant environmental, health, and safety problems; and as such, remains politicized. Research argues in favor of replacing nuclear energy with cleaner, less destructive renewable energy sources, such as solar and wind power. ${ }^{9}$

CONTACT Shams Al Din Al Hajjaji salhajjaji@aucegypt.edu @Weicker Building, University of Luxembourg, 4 Rue Alphonse Weicker, L-2721 Luxembourg.

${ }^{1}$ Treaty on the Non-Proliferation of Nuclear Weapon, art. I and II, July 1, 1968.

2 Nuclear Tipping Poin" introduction by General Powell, Nuclear Threat Initiate, YouTube (January 22, 2010), https://www.youtube.com/watch?v=ZgjPkDug_rU.

${ }^{3}$ ld.

${ }^{4}$ Grant Niemann, "Nuclear Weapons and the Civilian Use of Nuclear Energy," Flinders Law Journal 15 (191) (2013): 198.

${ }^{5}$ Nicholas Apergis and James Payne, "A Panel Study() of Nuclear Energy Consumption and Economics Growth," Energy Economics 32 (3) (2010): 545.

6 "Japan's Careful Return to Nuclear Power,"Bloomberg, March 10, 2016, https://www.bloomberg.com/view/articles/201603-10/japan-s-careful-return-to-nuclear-power; see also "Nuclear Power in Japan, World Nuclear Association," August 2016, http://www.world-nuclear.org/information-library/country-profiles/countries-g-n/japan-nuclear-power.aspx.

${ }^{7}$ Nuclear Energy Institute, "US Nuclear Power Plants, General US Nuclear Info," http://www.nei.org/Knowledge-Center/ Nuclear-Statistics/US-Nuclear-Power-Plants.

8 "Nuclear Power in the World Today," World Nuclear Association, August 2016, http://www.world-nuclear.org/ information-library/current-and-future-generation/nuclear-power-in-the-world-today.aspx.

9 David Repka and Smith Tyson, "Dose of History: Nuclear Energy Cases that Shaped Environmental Law," Natural Resources \& Environment 25 (1) (2010-2011): 28, 31.

๑) 2017 Taylor \& Francis Group, LLC 
This article opposes the use of nuclear energy for electricity generation, and promotes the implementation of energy policies emphasizing clean and renewable sources of power. The ideal energy policy should promote: (1) use of clean and renewable energy sources for electricity generation; and (2) reparation of environmental harms, including global climate change, caused by the use of nuclear energy and fossil fuels for power. ${ }^{10}$ An effective policy and plan to replace nuclear energy with renewables should authorize the International Atomic Energy Agency (IAEA) to play an active role in implementation and enforcement, so that we can fully reap the benefits of its expertise in addressing concerns tied to existing nuclear power facilities. The IAEA yearns to expand its role beyond the literature of articles III and IV of the NPT, a role that is limited to carrying out safeguard inspections and channeling the transfer of peaceful applications of nuclear technology. ${ }^{11}$

This article will separately address the basis for, and challenges and merits of, phasing out nuclear power generation and replacing it with renewables. The second section of this article discusses two areas of concern associated with nuclear power: international peace and security, and environmental health and safety. The third section proposes adoption of a clean energy policy which facilitates the replacement of nuclear power with renewables. An incomplete version of such a replacement policy has been adopted in Germany, and an absolute ban on nuclear power has been adopted in Italy. Several states in the United States have followed either Germany's or Italy's approach. The fourth section discusses two major challenges to implementing an effective replacement program: (1) achieving wide-scale implementation in a way that does not conflict with state sovereignty; and (2) providing economic and social incentives to phase out nuclear power from the electricity industry and to replace it with renewables. The fifth section concludes with a reiteration of the merits of adopting a policy and program that replaces nuclear energy with renewables.

\section{Problems}

Nuclear power generation engenders significant harms both on- and off-site: reactor explosions, threats to other governments of weapons production under the guise of power generation, acts of terrorism, ${ }^{12}$ and health and safety issues that result even from ordinary operation of power plants. ${ }^{13}$ Illegal political intervention (allegations of enriched uranium, as those the United States. raised against Iraq) and environmental disasters (reactor explosions, as occurred in Fukushima) are two areas of concern associated with nuclear power generation, and are discussed in turn below.

Iraq began storing uranium in Tuwaitha in 1991. ${ }^{14}$ In 2003 the U.S. administration claimed that Iraq owned weapons of mass destruction. George W. Bush

\footnotetext{
${ }^{10}$ Stephan McCaffrey, "The Work of the International Law Commission Relating to Transfrontier Environmental Harm," New York University Journal of International Law \& Politics 20 (2) (1987-1988): 715, 722.

11 "Key Roles" (2016), IAEA, https://www.iaea.org/newscenter/focus/npt/key-roles.

12 International Convention for Suppression of Acts of Nuclear Terrorism.

${ }^{13}$ Convention on Nuclear Safety.

14 "Nuclear," Central Intelligence Agency, https://www.cia.gov/library/reports/general-reports-1/iraq_wmd_2004/chap4. html.
} 
stated: "Either you are with us, either you love freedom and [are] with nations which embrace freedom, or you are with the enemy. There's no in-between." ${ }^{15}$ IAEA defended Iraq, declaring that "the safeguarded material is low-enriched, natural, and depleted uranium. The Iraqi counterpart has provided the necessary cooperation for the IAEA team to perform its activities satisfactorily." ${ }^{16}$ Both Germany and France, despite being allies of the United States during their war in Afghanistan, did not support the United States' claim. Then-president of France Jacques Chirac revealed in an interview with $\mathrm{CNN}$ in 2003 why he was opposing the war against Saddam Husain's regime in Iraq: "If I see my friend, or someone I dearly love going down the wrong path, then I owe it to him to tell him, to warn him: be careful. From my experience on the international political stage, I am telling my American friends ... beware, be careful ... This can be very dangerous." ${ }^{17}$ Under the polarizing lens of George W. Bush's "with us or against us" rhetoric, the question is whether France joined the enemy unjustifiably, or if the war was in fact illegally waged by the United States. ${ }^{18}$ Kofi Annan, the former UN secretary-general, said, "The U.S.-led invasion of Iraq was an illegal act that contravened the UN Charter." ${ }^{19}$ As a result, the UN and IAEA refused to declare Iraq in possession of weapons of mass destruction.

Long after the damage wrought by the nuclear bombing of Japan in World War II, the economy and environment of the country suffered significantly from nuclear energy generation for peaceful purposes when an earthquake's impact reached the nuclear power plant in Fukushima. ${ }^{20}$ On March 11, 2011, an earthquake struck off the east coast of Honshu, ${ }^{21}$ causing a power outage at the nuclear power plant in Fukushima, 109 miles from the quake's epicenter. Without power to run the cooling system of the reactor, hydrogen built up, causing explosions in four of the plant's six units. $^{22}$ Despite safety precautions that caused damaged reactors to automatically shut down to avoid further harm, more than 20,000 people were killed. The radiation resulting from the explosion crossed the Pacific Ocean ${ }^{23}$ : radioactive materials have been detected off the coast of California. ${ }^{24}$ As this tragedy demonstrates, there is a pressing need to move away from nuclear power.

\footnotetext{
${ }^{15}$ With Us or Against Us, YouTube (March 7, 2008), http://www.youtube.com/watch?v=-23kmhc3P8U.

${ }^{16} \mathrm{https} / / /$ www.iaea.org/newscenter/news/iaea-team-concludes-inspections-iraq.

${ }^{17}$ Be Careful! Chirac to USA, (Jacques Chirac interview with CNN), YouTube (December 24, 2010), http://www. youtube.com/watch?v=wX2rS6p3akw.

18 Shams Al Din Al Hajjaji, "Review of the New Global Law by Rafael Domingo," Berkeley Journal of International Law 32 (1) 2014: 268, 280.

19 "Iraq War Illegal, Says Annan," BBC News, September 16, 2004, http://news.bbc.co.uk/2/hi/middle_east/3661134.stm.

${ }^{20}$ Katherine Trisolini, "Decisions, Disasters,() and Defense: Rethinking Agency Expertise after Fukushima," Yale Law \& Policy Review 33 (2) (2015): 323, 371.

${ }^{21}$ Hasan Selim Ozertem, "Fukushima Sonrasi Turkiye de Nukleer Enerji Politikalari," Review of International Law \& Politics 7 (1) (2011): 157, 158.

22 "Fukushima Accident," World Nuclear Association, April 2017, http://www.world-nuclear.org/information-library/ safety-and-security/safety-of-plants/fukushima-accident.aspx.

${ }^{23}$ Ken Buesseler, "5 Years Later, Fukushima Radiation Continues to Seep into the Pacific Ocean," PBS, March 9, 2016, http://www.pbs.org/newshour/updates/fukushima-radiation-continues-to-leak-into-the-pacific-ocean/.

${ }^{24}$ Greg White, "Record Fukushima Radiation Levels Found on Southern California Coast," Fukushima Watch, December 14, 2015, http://www.fukushimawatch.com/2015-08-28-record-fukushima-radiation-levels-found-on-southern-californiacoast.html.
} 
The Fukushima power plant incident also raises questions about the global response to nuclear reactors. The international response to the Fukushima disaster was bifurcated: within the United States, states called either for suspending or expanding their respective nuclear power operations. ${ }^{25}$ Developed countries, including Italy, tended more to suspend their nuclear power operations, whereas developing countries, including Egypt and the United Arab Emirates, tended to opt for expanding their nuclear power industry by building new reactors. Article III mandates that the IAEA urge reluctant states to replace their nuclear power operations with renewable energy programs. It is expected that if developed countries replace or abandon their nuclear programs, developing countries will follow suit.

\section{Solutions}

An effective energy policy will aim to replace nuclear power generation with clean energy technologies, especially in developing countries in the Middle East. This requires, as an initial matter, discouraging new countries from owning or operating nuclear reactors. Egypt, Turkey, and the United Arab Emirates are among those countries promoting the construction and operation of nuclear power plants. ${ }^{26}$ The IAEA is encouraging these countries to abandon nuclear energy and replace it with clean and renewable energy generation. An effective energy policy will simultaneously focus on encouraging countries that currently have nuclear power programs to replace their nuclear operations with renewable alternatives. Middle Eastern countries are chief among this set. The adoption of new energy policies should be given priority for two reasons: ${ }^{27}$ the political unrest that may be exacerbated by the presence of nuclear power facilities, and the affordability of renewables such as wind and solar power as alternative sources of energy.

In 2000 Germany owned seventeen reactors, which accounted for approximately 27 percent of its total produced energy. ${ }^{28}$ The government has adopted a policy to replace its nuclear energy program with other sources of energy. ${ }^{29}$ Germany plans to roll out the next edition of its policy for replacing nuclear power with alternative sources of power by 2022. The policy adopted by Germany seeks to eliminate nuclear power by phasing out the operations over time, and by requiring that plants at the end of their life span be replaced with non-nuclear energy operations. ${ }^{30}$ This article argues for a more aggressive policy, which would require an immediate replacement of nuclear power operations with clean, renewable energy. Although the percentage

\footnotetext{
${ }^{25}$ Lincoln Davies and Alexis Jones, "Fukushima's Shadow," Vanderbilt Journal of Transnational Law 48 (4) (2015): 1083.

${ }^{26}$ Yousef Haik, "Nanotechnology in the United Arab Emirates: Hype and Hope," Nanotechnology Law \& Business 5 (2) (2008): 219, 222.

${ }^{27}$ Mohamed Ibrahim Shaker, "Regionalizing Nuclear Energy in the Middle East: Making Progress on the Nuclear- and WMD- Free Zone," Global Governance 20 (4) (2014): 517.

${ }^{28}$ Robert Kunzing, "German Could Be a Model for How We'll Get Power in the Future," National Geographic, October 15, 2015, http://ngm.nationalgeographic.com/2015/11/climate-change/germany-renewable-energy-revolution-text.

${ }^{29}$ Lars Kramm, "The German Nuclear Phase-out After Fukushima, A Peculiar Path or an Example for Others?" Renewable Energy Law \& Policy Review 2012: 251, 254.

${ }^{30}$ Lincoln Davies, "Beyond Fukushima; Disasters, Nuclear Energy, and Energy Law," Brigham Young University Law Review $6(2011): 1937,1948$.
} 
of renewable energy generated from wind, sun, and biogas has increased from 6 percent in 2000 to 30 percent in $2014,{ }^{31}$ Germany still relies significantly on coal and other fossil fuels; ${ }^{32}$ these account for more than 60 percent of its total electricity generation and consumption. Coal and other fossil fuels are not environmentally friendly, as the process of burning them to produce electricity emits large amounts of sulfur dioxide, nitrogen oxide, and carcinogens, increasing the toxicity of our environment and exacerbating global climate change. ${ }^{33}$

\section{Challenges}

The adoption of an effective energy policy like that described above faces several challenges. This section focuses on three of them, and is by no means exhaustive: state sovereignty, economic incentives to develop and nurture new industries employing renewables, and economic incentives to abandon current nuclear power operations.

It has been argued that policies requiring replacement of nuclear power with clean energy will compromise state sovereignty under the Tenth Amendment of the U.S. Constitution. ${ }^{34}$ States have the absolute right to control their own energy operations and sources of fuel employed. ${ }^{35}$ The threat posed by the Tenth Amendment is lessened by the unobjectionability of the desired behavior-as indicated by cultural trends toward sustainability - and by limitations to what may be resisted or challenged as conflicting with state sovereignty. More and more countries are moving, albeit at different paces, towards sustainable development and the use of renewable energy sources. ${ }^{36}$ State sovereignty is no longer a buzzword freely used to resist majority-held views in international law. Going against the majority by repudiating a replacement program jeopardizes a country's international reputation ${ }^{37}$ and may result in retaliation against it through economic or social sanctions, as with the United States' retaliation against the Sudanese and Russian governments. ${ }^{38}$

An effective energy policy must rely upon incentivizing countries to adopt a replacement plan voluntarily, and not seek to force it upon them. The international community shall offer incentives for developing countries to overcome the issue of the absence of international incentives. These incentives will help the developing countries to adopt such a policy. They can be summarized in three points: (1) developed countries, the World Bank, or the IMF would facilitate loans for such a

\footnotetext{
${ }^{31}$ Michael Trachtenberg and Gal Henchman, "Ethical Energy and the Clean Election," Villanova Environmental Law Journal 25 (1) (2014): 121, 145.

32 “Germany Warns against Rushed Exit from Coal Power," Reuters, January 19, 2016, http://www.reuters.com/article/rwecoal-idUSL8N1531X2.

${ }^{33}$ M. A. Wojtowicz et al., "Combustion of Coal as a Source of N2O Emission," Fuel Processing Technologies 34 (1) (1993): 5.

${ }^{34}$ W. Jethro Brown, "Sovereignty," 18 Judicial Review, 18 (1) (1906-1907): 1, 6.

${ }^{35}$ Richard Lazarus, "Changing Conceptions of Property and Sovereignty in Natural Resources: Questioning the Public Trust Doctrine," lowa Law Review 70 (3) (1985-1986): 631, 664.

${ }^{36}$ Mohamed el-Ashry, "Clean Energy and Sustainable Development," Environmental Policy \& Law 35 (2) (2005): 92, 92-93.

${ }^{37}$ Andrew Guzman, How International Law Works: A Rational Choice Theory, 25 (Oxford 2007).

${ }^{38}$ Oona Hathaway, "Between Power and Principle: An Integrated Theory of International Law," University of Chicago Law Review 72 (2) (2005): 469, 475.
} 
purpose, and reschedule debts; ${ }^{39}$ (2) developed countries would introduce clean energy technology to developing countries at competitive prices; ${ }^{40}$ and (3) public officials would be educated and trained in relation to the benefits of adopting clean energy, which include both environmental and economic gains.

The high initial cost of establishing a new industry employing clean energy technology, relative to the cost of producing a nuclear reactor through existing infrastructure, ${ }^{41}$ is a challenge to implementation of a policy requiring replacement of nuclear with renewable energy. Some countries argue that nuclear reactors and plants are cheaper to construct and operate than are facilities utilizing cleaner renewable energy sources. ${ }^{42}$ This argument discounts or even ignores the soft costs associated with building and operating nuclear power facilities. ${ }^{43}$ The social costs, including political, health, safety, and environmental externalities, are high-even by the limited extent to which they are recognized in a plant's operating expenses. ${ }^{44}$ It is expensive to maintain security for such a hotly contested operation, and the facilities must be protected against terrorist attacks. The cost of building a nuclear reactor has significantly increased since the events at Fukushima. Egypt has signed a deal with Russia pricing the endeavor at $\$ 25$ billion; ${ }^{45}$ the Egyptian president justifies this high cost by citing safety reasons. ${ }^{46}$ Nuclear energy is not in fact less costly than renewables.

In the absence of strong incentives, the third challenge to implementing an effective energy policy relates specifically to persuading developing countries to abandon their existing nuclear power policies. Developing countries resist such efforts under a suspicion rooted in conspiracy theory: the notion that the objective is to prevent developing countries from becoming developed and rivaling the global superpowers. This fear is unfounded in light of new innovations in clean energy and renewables. There are many opportunities for growth presented by new clean energy empires: Tesla ${ }^{47}$ has developed new technologies that make car batteries last for 450 miles, without the use of nuclear power or fossil fuels. ${ }^{48}$ The company

\footnotetext{
${ }^{39}$ Alan Miller and Eric Martinot, "The GEF: Financing and Regulatory Support for Clean Energy," Natural Resources \& Environment 58 (1) (2000-2001): 164, 164-165.

${ }^{40}$ Ujjwai Kacher, "Technology Transfer and Financing Issues for Long-Term Climate Policy in Developing Countries," Carbon \& Climate Law Review 2009: 292, 298.

${ }^{41}$ Robert Bryce, "The High Cost of Renewable- Electricity Mandates," Manhattan Institute, February 2012, http://www. renewable-energysources.com/.

${ }^{42}$ Lamar Alexander, "Nuclear Energy is Cheap and Reliable," US News, July 19, 2010, https://www.usnews.com/opinion/ articles/2010/07/19/lamar-alexander-nuclear-energy-is-cheap-and-reliable.

${ }^{43} \mathrm{Hard}$ cost is the actual physical cost of a given project, while the soft costs are usually not directly related to the physical cost of the project. For example, hard cost would be the cost for building, while the soft cost will be the maintenance and insurance of the building. Benjamin Miller, "Real Estate 101: The Difference between Hard and Soft Construction Cost," Fundrise, January 30, 2015, https://fundrise.com/education/blog-posts/real-estate-101-the-difference-betweenhard-and-soft-construction-costs.

${ }^{44}$ Bernard Leonard, ed., The Economics of Nuclear Energy, 286 (Springer).

${ }^{45}$ Asma Al-Sharif, "Russia to Lend Egypt \$25 Billion to Build Nuclear Power Plant," Reuters, May 19, 2016, http://www. reuters.com/article/us-egypt-russia-nuclear-idUSKCNOYA1G5.

${ }^{46}$ Eric Trager, "Egypt's Costly Nuclear Project," The Washington Institute, Policy Analysis, June 16, 2016, http://www. washingtoninstitute.org/policy-analysis/view/egypts-costly-nuclear-project.

${ }^{47}$ Russ Mitchell, "Can Tesla Go from Sexy Car Company to Clean Energy Empire?" Los Angeles Times, August 6, 2016, http:// www.latimes.com/business/autos/la-fi-hy-tesla-sells-solar-20160807-snap-story.html.

${ }^{48}$ Katie Fehrenbacher, "Why Tesla is Making a New Battery Format at the Gigafactory," Fortune, July 27, 2016, http:// fortune.com/2016/07/27/tesla-bigger-battery-gigafactory/.
} 
plans to release vehicles at competitive prices, which would start a revolution in the battery and automotive industry. Replacing nuclear power would be especially beneficial for developing countries that happen to be rich with clean energy sources, such as Middle Eastern countries. It equips them with a sustainable source of energy and a safer environment. ${ }^{49}$

\section{v. Conclusion}

The continued use of nuclear energy is a pressing problem in today's environmental world. Although the issue is multifaceted, two principle aspects of nuclear energy are political crises, like those of Iraq, and environmental disasters, like that of Fukushima. Both political crises and environmental disasters can occur or have repercussions even in the most developed countries in the world, and can be felt even across oceans. A full replacement policy of nuclear power with clean energy alternatives is crucial to reducing the social, economic, and environmental costs of powering countries in the modern world. Some developed countries have already adopted a replacement policy of nuclear energy - thus demonstrating the feasibility of, and recognition of the need for, such a transition. Although there are major challenges to implementing an effective clean energy policy, new renewable energy technologies present opportunities for sustainable growth in developing countries. Coupled with domestic and international social and political pressure and support, an understanding of the true costs of nuclear power versus renewables will also facilitate adoption of such policies in more developed countries.

\section{Acknowledgments}

The author wishes to extend his deep gratitude and appreciation to Howard Tollin, Jenna Fierstein, and Claire Weyland for their helpful edits, and my wife for her continuous help and support.

\section{About the authors}

Shams Al Din Al Hajjaji is a judge at North Cairo Primary Court.

\footnotetext{
${ }^{49}$ Louise Sarant, "The Rise of Solar Energy in Egypt," Middle East Institute, February 18, 2015, http://www.mei.edu/ content/article/rise-solar-energy-egypt.
} 